\title{
PROFIL 24 JAM KUAT PENERANGAN, SUHU UDARA, KELEMBABAN UDARA DI LUAR DAN DI DALAM HUTAN MANGROVE
}

\author{
Profile 24 Hours Intensity, Air Temperature, Air Humidity Outside and in \\ Mangrove Forest
}

\author{
Mario Nikolaus Dalengkade*
}

Program Studi Matematika Fakultas Ilmu Alam dan Teknologi Rekayasa Universitas Halmahera Jl. Wari Raya, Tobelo, Halmahera Utara, 97762, Indonesia

e-mail:*mariodalengkade@gmail.com

Corresponding author*

\begin{abstract}
Abstrak
Fenomena perubahan iklim yang terjadi dalam distribusi pola cuaca secara statistik sepanjang periode waktu mengalami perubahan. Perubahan tersebut akan berimplikasi pada kondisi abiotik secara mikro. Sebagai studi kasus, profil kondisi abiotik pada ekosistem mangrove menarik untuk dikaji dalam fungsi Fourier. Penelitian ini bertujuan menjelaskan hubungan antar variabel cuaca yakni kuat penerangan, suhu udara, dan kelembaban udara menggunakan fungsi Fourier $f(t)=T_{0} \sum_{m=0}^{N / 2} a_{m} \cos \omega_{m} t+b_{m} \sin \omega_{m} t$. Hasil kajian menunjukkan bahwa kuat penerangan posisi 1 untuk titik terluar dan posisi 3 untuk titik tepi memaparkan grafik yang lebih tinggi dari posisi 9 pada titik dalam hutan mangrove, dengan puncak penyinaran pukul 12.00 sebesar 51,210 lux. Suhu udara sejak pukul 19.00-04.00 mengalami penurunan, dan naik kembali hingga pukul 13.00 mencapai titik maksimum $34,6^{\circ} \mathrm{C}$. Hasil suhu udara berbanding terbalik dengan kelembaban udara, dimana pukul 19.00-04.00 mengalami kenaikan dan kembali menurun mencapai batas minimum 59,9\% pada pukul 13.00. Selain itu, korelasi silang menunjukan respon suhu udara dan kelembaban udara secara konsisten memperlihatkan difusi termal yakni 1,0 jam dari posisi 1 sampai posisi 3, sedangkan posisi 3 sampai posisi 9 yakni 1,0 jam - 1,2 jam. Data tersebut mengindikasikan bahwa hutan mangrove mampu mereduksi difusi termal arah vertikal.
\end{abstract}

Kata Kunci: Cuaca, pemodelan, fungsi Fourier, mangrove.

\begin{abstract}
The phenomenon of climate change that occurs in statistical distribution patterns throughout the period of change in variation. These changes would be implications for micro abiotic conditions. As a case study, the abiotic condition profile in mangrove ecosystems is interesting to study in the Fourier function. This study aims to describe the relationship between weather variables such as intensity, air temperature, and humidity using the Fourier function $f(t)=T_{0} \sum_{m=0}^{N / 2} a_{m} \cos \omega_{m} t+b_{m} \sin \omega_{m} t$. The results of the study showed that the intensity of position 1 (the outermost point) and position 3 (the edge point) presented a graphic higher than position 9 (the point in) the mangrove forest, with a peak illumination at 12.00 at 51,210 lux. The air temperature at 19.00-04.00 has decreased and rises again until 13.00 $o^{\prime}$ 'clock reached a maximum point of $34,6^{\circ} \mathrm{C}$. The air temperature is inversely proportional to the humidity, at 19.00 to 04.00 an increase and again decreased to reached the minimum limit of 59,9\% at 13.00 o'clock. In addition, cross-correlation showed of the air temperature and humidity consistently presented thermal diffusion of 1,0 hours from position 1 to position 3, while positions 3 to position 9 are 1,0 hours - 1,2 hours. Data indicate that mangrove forests can reduce vertical thermal diffusion.
\end{abstract}

Keywords: Weather, modeling, Fourier functions, mangrove. 


\section{PENDAHULUAN}

Belakangan ini isu mengenai perubahan iklim menarik perhatian para pakar lingkungan untuk membuktikan hal tersebut. Salah satu faktor terjadinya perubahan iklim yakni meningkatnya $\mathrm{CO}_{2}(\mathrm{karbon}$ dioksida) di atmosfer. Peningkatan $\mathrm{CO}_{2}$ menurut [1] terjadi karena anthropization. Salah satu hutan yang dialihkan fungsinya yakni hutan mangrove. Tercatat hilangnya mangrove mencapai $30 \%-50 \%$ dari luas keseluruhan 16.530.000 Ha di dunia dalam 100 tahun terakhir, dan diikuti oleh akumulasi $\mathrm{CO}_{2}$ sebesar 280 ppm-380 ppm. Apabila berlanjut sampai tahun 2050 maka $\mathrm{CO}_{2}$ diprediksi akan menyentuh angka $600 \mathrm{ppm}$, sehingga mengakibatkan perubahan iklim secara global [2], [3]. Disamping itu, dampak lain karena berkurangnya mangrove yakni pada tahun 1985 di Bangladesh sebanyak 40.000 ribu penduduk mendiami daerah pesisir mengalami kerugian material karena hantaman badai. Mengantisipasi kejadian tersebut pemerintah Bangladesh melakukan penanaman kembali seluas $25.000 \mathrm{Ha}$ areal pantai dengan vegetasi mangrove [4].

Tertuang dalam laporan [5], [6], [7] bahwa pada kedalam >30 meter dari permukaan tanah dan diatas permukaan tanah total peyimpanan $\mathrm{C}$ (karbon) yakni $334 \mathrm{Mg} \mathrm{C}$ ha $^{-1}$ untuk kawasan Boreal, kawasan Temperate yakni $320 \mathrm{Mg} \mathrm{C}^{-1}$, dan kawasan Tropical Upland sebesar $250 \mathrm{Mg} \mathrm{C}^{-1}$, serta kawasan Mangrove Indo-Pacific adalah $1.000 \mathrm{Mg} \mathrm{C}^{-1}$. Melanjutkan temuan tersebut [3] melaporkan pengukuran dari batas/tepi ke dalam mangrove sepanjang transek pengukuran dengan jarak $10 \mathrm{~m}, 35 \mathrm{~m}, 60 \mathrm{~m}, 85 \mathrm{~m}, 110$ m, dan $135 \mathrm{~m}$ di atas permukaan tanah serta lapisannya pada kawasan Estuarine Mangroves. Diketahui C yang tersimpan berturut-turut untuk jarak tersebut yakni $1.190 \mathrm{Mg} \mathrm{C}^{-1}, 1.080 \mathrm{Mg} \mathrm{C}^{-1}, 1.300 \mathrm{Mg} \mathrm{C}$ ha${ }^{1}, 1.220 \mathrm{Mg} \mathrm{C}^{-1}, 1.210 \mathrm{Mg} \mathrm{C} \mathrm{ha}^{-1}, 1.210 \mathrm{Mg} \mathrm{C}^{-1}$. Sedangkan kawasan Oceanic Mangroves dengan jarak tersebut penyimpanan C yakni $930 \mathrm{Mg} \mathrm{C}^{-1}, 900 \mathrm{Mg} \mathrm{C}^{-1}, 1.020 \mathrm{Mg} \mathrm{C}^{-1}, 940 \mathrm{Mg} \mathrm{C}^{-1}, 11.090 \mathrm{Mg}$ $\mathrm{C}$ ha-1, $1.120 \mathrm{Mg} \mathrm{C}^{-1}$. Pihak lain [8] melaporkan bahwa kapasitas penyerapan $\mathrm{CO}_{2}$ oleh Tropical forest sebesar $6 \mathrm{~g} \mathrm{C} \mathrm{m}^{-2} \mathrm{yr}^{-1}$, Boreal forest $7 \mathrm{~g} \mathrm{C} \mathrm{m}^{-2} \mathrm{yr}^{-1}$, Temperate forest 7,2 $\mathrm{g} \mathrm{C} \mathrm{m}^{-2} \mathrm{yr}^{-1}$, Salt Marshes $400 \mathrm{~g} \mathrm{C}$ $\mathrm{m}^{-2} \mathrm{yr}^{-1}$, Mangrove $400 \mathrm{~g} \mathrm{C} \mathrm{m}^{-2} \mathrm{yr}^{-1}$, dan Seagrasses $200 \mathrm{~g} \mathrm{C} \mathrm{m}^{-2} \mathrm{yr}^{-1}$. Laporan-laporan tersebut menegaskan secara jelas bahwa organisme sangat bergantung pada ekosistem hutan terutama mangrove, karena daya simpan $\mathrm{C}$ sangat besar dan penyerapan $\mathrm{CO}_{2}$ di atmosfer.

Lain dari pada penyelidikan di atas oleh [9], [10] menyatakan perombakan mangrove menyebabkan perubahan kondisi fisik, termasuk iklim mikro. Menurut [11] iklim tersebut yakni gambaran kondisi fisik atmosfer dengan rentang skala 0.001 hingga $100 \mathrm{~m}$ dan variabel-variabel yang termasuk kedalam iklim mikro yakni daya tembus cahaya matahari (sunlight exposure), daya tembus 48armon (wind exposure), presipitasi (curah hujan), suhu udara (tanah/udara), serta kelembaban udara (tanah/udara). Kajian-kajian 48armonic iklim mikro yang diteliti oleh [12] pada kawasan hutan berbatasan dengan 48armoni menggunakan formula $f(x)=a+(c+a) /(1+\exp ((x-b) / d))$. Sebagai contoh hasil kajian salah satu 48armonic iklim mikro yakni kelembaban udara yang di ukur sepanjang transek $400 \mathrm{~m}$ (-200 m 48armoni 48armoni dan $200 \mathrm{~m}$ ke dalam hutan) menunjukan 48armoni kelembaban udara sebesar 5\%-30\% dari dalam hutan ke area 48armoni sehingga membentuk luaran grafik eksponesial (perubahan kuantitas kelembaban udara secara eksponensial berubah dari waktu ke waktu). Peneliti lain [13] melaporkan hutan yang terletak di Pacific Northwest mempertontonkan perubahan suhu udara sejak pukul $06.00-13.00$ sebesar $7^{\circ} \mathrm{C}-27^{\circ} \mathrm{C}$ dari tepi hutan ke area terluar hutan, sedangkan suhu udara dari tepi ke dalam hutan yakni $9^{0} \mathrm{C}-21^{\circ} \mathrm{C}$. Kenaikan suhu udara tersebut sejalan dengan kenaikan kuat intensitas matahari sejak pukul $06.00-13.00$ sebesar $0 \mathrm{~kW} \mathrm{~m}^{-2}$ hingga $0.9 \mathrm{~kW}$ $\mathrm{m}^{-2}$. Hal ini mengindikasikan bahwa perubahan suhu udara dipengaruhi oleh kuatnya intensitas penyinaran matahari. Hasil kajian ekologi [14], [15], [16] mengungkapkan 48armonic iklim mikro berperan penting dalam proses fisologi (fotosintesis, respirasi, aktivitas enzim), dan menunjang kehidupan biota air, flora, fauna, serta berbagai mikroorganisme. Ada pun pihak lain [17], [18], [19], [20] menginformasikan 48armonic iklim mikro sangat peka terhadap perubahan termal baik di dalam hutan maupun lingkungan sekitarnya. Dan dukungan studi empiris dalam tambalan serta lintas batas tambalan menunjukan struktur bentang alam dapat ditentukan, didelineasi menggunakan data-data iklim mikro [13].

Variabel-variabel iklim mikro yang pernah dikaji di atas yakni merupakan suatu deret waktu, sehingga 48armonic tersebut dapat dianalisis menggunakan analisis Fourier. Analogi sederhana guna memahami analisis Fourier dalam menganalisis 48armonic iklim mikro yakni, misalkan panas yang dihasilkan oleh matahari ialah cahaya (intensitas matahari) dalam dunia fisika merupakan gelombang sinus atau cosinus. Sehingga gelombang tersebut dapat diuraikan menjadi komponen sinusoida-nya. Menurut [21], [22], [23], [24], [25] jika deret Fourier dinyatakan dengan fungsi 48armonic $f(t)=F(t-T)$, dimana $T$ merupakan nilai terkecil dari periode yang mungkin diperoleh jika $f(t)$. Maka $f(t)$ memenuhi syarat Dirichlet, sehingga $f(t)$ dapat dijabarkan kedalam deret suku-suku 48armonic sinus/kosinus yang ditunjukan pada persamaan 1 . 


$$
f(t)=\frac{a_{0}}{2}+\sum_{n=1}^{\infty}\left(a_{n} \operatorname{Cos} n \omega t+b_{n} \operatorname{Sin} n \omega t\right)
$$

Pada persamaan (1) besaran $\omega$ merupakan suatu konstanta matematik yang memiliki makna fisis memenuhi formula $\omega=2 \pi / T$ dimana $T$ merupakan 49armonic waktu, maka $\omega$ berfungsi sebagai parameter frekuensi bernilai waktu. Menelaah kembali uraian di atas mengenai pentingnya ekosistem mangrove, dan pejelasan fungsi Fourier. Maka yang menjadi pertanyaan menarik yakni "Bagaimana fluktuasi cuaca selama 24 jam dari 49armonic kuat penerangan, suhu udara, dan kelembaban udara menggunakan fungsi Fourier". Karena menurut [13], [26] 49armonic cuaca tersebut berfungsi sebagai studi lapangan, pemodelan teoritik, dan pemantauan perubahan iklim.

\section{METODE PENELITIAN}

Pemodelan 49armonic cuaca dalam penelitian ini didasarkan pada model matematik. Variabel cuaca yang diukur yakni kuat penerangan/intensitas cahaya matahari $(I)$, suhu udara $(T)$, dan kelembaban udara $(H)$ dengan menggunakan fungsi Fourier. Sehingga pemodelan 49armonic yang dimaksud dari hasil pungukuran menghasilkan fungsi semata. Penggunaan fungsi Fourier untuk penelitian ini yakni mentransformasikan informasi waktu ke informasi frekuensi. Maka setiap 49armonic cuaca yang teramati memperoleh periode maksimum. Periode 49armonic cuaca diasumsikan sama pada satuan waktu maupun tempat yang berbeda. Mengacu dari penjelasan tersebut fungsi Fourier untuk menganalisis 49armonic cuaca adalah [27], [28] :

Dimana :

$$
f(t)=T_{0} \sum_{m=0}^{\frac{N}{2}} a_{m} \cos \omega_{m} t+b_{m} \sin \omega_{m} t
$$

$$
\begin{aligned}
& \omega_{m}=\frac{2 \pi m}{N} \\
& a_{m}=\frac{2}{N} \sum_{t=0}^{N-1} f(t) \cos \omega_{m} t \\
& b_{m}=\frac{2}{N} \sum_{t=0}^{N-1} f(t) \sin \omega_{m} t
\end{aligned}
$$

$m$ yakni cacah suku deret Fourier dan $N$ adalah banyaknya data (pasangan data 49armonic bebas waktu $(t)$ dan 49armonic terikat kuat penerangan $(I)$, suhu udara $(T)$, kelembaban udara $(H), f(t)$ adalah suhu udara hasil pengukuran di lapangan, $a_{m}$ dan $b_{m}$ adalah koefisien Fourier. Pengukuran setiap 49armonic $(I, T$, dan $H)$ selama 25 jam dengan interval waktu 1 jam, sehingga menghasilkan $N=25$. Harga $N=25$, karena dalam pelaksanaan pengambilan data 49armonic penelitian dengan cara berpindah-pindah sepanjang transek $4 \mathrm{~m}$ dan $2 \mathrm{~m}$ dari tepi 49armoni luar hutan mangrove, di tepi (sebagai posisi acuan: $x=0$ ), serta pada jarak $1 \mathrm{~m}$, $2 \mathrm{~m}, 4 \mathrm{~m}, 8 \mathrm{~m}, 16 \mathrm{~m}$, dan $32 \mathrm{~m}$ dari tepi ke dalam mangrove. Pelaksanaan tersebut memiliki selisih waktu pengukuran untuk setiap posisi, dan selisih tersebut dicatat guna sinkronisasi data. Pengukuran setiap 49armonic dimulai dari jam 06.00-18.00, sehingga diperoleh data $N=13$. Banyaknya 49armonic yakni $N / 2$, maka untuk 25 data pengamatan, nilai $m$ yakni : $1,2,3, \ldots \ldots, 12$. Untuk jumlah $N=13$, data pengamatan $m=$ $1,2,3, \ldots \ldots, 6$. Prosedur pemodelan setiap 49armonic cuaca yakni :

1. Menentukan harga koefisien $a_{m}$ dan $b_{m}$ meggunakan persaman (4) serta persamaan (5).

2. Menentukan koefisien $c_{m}^{2}=a_{m}^{2}+b_{m}^{2}$.

3. Menentukan sumbangan keragaman: $s_{m}=\left(c_{m}^{2} /(2 . \sigma)\right) * 100$.

4. Sinkronisasi data antar posisi pengukuran. Sinkronisasi data dilakukan karena pengukuran tidak serempak, tapi berpindah dari posisi satu ke posisi lainnya sepanjang transek. Sinkronisasi data ini 
dilakukan dengan memasukan data selisih waktu pengukuran dari posisi satu ke posisi selanjutnya, ke dalam fungsi berikutnya. Sinkronisasi ini tidak mengubah fungsi tapi memberikan yang harga baru untuk setiap posisi.

5. Uji korelasi silang (cross-correlation). Uji korelasi silang ditunjukan guna menghitung time-delay perubahan antara 50armonic kuat penerang terhadap 50armonic suhu udara dan perubahan 50armonic kuat penerang terhadap kelembaban udara. Persamaan yang digunakan untuk menentukan korelasi silang [29] yakni :

$$
\left.r=\sum_{i}^{n}\{(x(i)-m x)) \cdot(y(i-d)-m y)\right\} / \operatorname{sqr}\left\{\sum_{i}^{n}\left(x((i)-m x)^{2}\right\} . \operatorname{sqr}\left\{\sum_{i}^{n}\left(y((i-d)-m y)^{2}\right\}\right.\right.
$$

Dimana : $r=$ koefisien korelasi, $n=$ banyaknya pasangan data $x$ (peubah bebas) dan $y$ (peubah terikat), $i=$ cacah data, $d=$ time-delay antar 50armonic $x$, serta $y$. Untuk menentukan delay antara $x$ dan $y$ yakni dari nilai maksimal $r$. Proses penentuan delay yakni menggeser salah satu fungsi (misalnya $y$ ) terhadap $x$ (proses iterasi). Prosedur pergeseran yakni mengiterasi $d$ dengan interval tertentu. Nilai $d$ awal dapat dipilih sama dengan nol atau menggunakan nilai tertentu jika terdapat acuan delay kedua fungsi. Penggeseran diteruskan selama $r$ bertambah dan dihentikan ketika mencapai nilai tertinggi. Delay kedua fungsi adalah nilai $d$ ketika nilai $r$ maksimal.

\section{HASIL DAN PEMBAHASAN}

\subsection{Deskripsi Transek Pengkuran}

Keterangan transek pengukuran 50armonic cuaca pada ekosistem mangrove berbatasan dengan pantai diperlihatkan oleh Tabel 1.

Tabel 1. Koordinat Transek Pengukuran

\begin{tabular}{|c|c|c|c|c|c|c|c|c|}
\hline \multirow{3}{*}{ 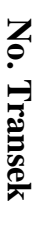 } & \multicolumn{4}{|c|}{ Posisi (Koordinat) Titik Ujung Transek } & \multirow{3}{*}{$\overbrace{}^{\theta}$} & \multirow{2}{*}{\multicolumn{3}{|c|}{ Jarak Ke Batas Ekosistem (m) }} \\
\hline & \multicolumn{2}{|c|}{ Luar Hutan Mangrove } & \multicolumn{2}{|c|}{ Dalam Hutan Mangrove } & & & & \\
\hline & Lintang & Bujur & Lintang & Bujur & & Arah Transek & Kiri & Kanan \\
\hline 1. & $0^{0} 5^{\prime} 59.76^{\prime \prime}$ & $\begin{array}{c}124^{0} 42^{\prime} 29 . \\
68^{\prime \prime}\end{array}$ & $0^{0} 5^{\prime} 59.78^{\prime \prime}$ & $\begin{array}{c}124^{0} 42^{\prime} 27.6 \\
6 ”\end{array}$ & 70 & 722 & 141 & 665 \\
\hline
\end{tabular}

Topografi lokasi transek pengukuran disajikan oleh 50armo 1 yakni berbatasan dengan pantai ditumbuhi pohon besar. Penggenaan air laut berkisar 3 jam, pada saat air pasang maksimum. Species mangrove yang tumbuh yakni dari berbagai species dengan kerapatan tutupan kanopi $68 \%-74 \%$.

\subsection{Pemodelan Kuat Penerangan (I)}

Mengacu pada prosedur dan teknik analisis pemodelan cuaca terkait 50armonic yang diteliti dalam metode penelitian, menghasilkan data pemodelan ditunjukkan oleh 50armo 2. Dalam penelitian ini sesungguhnya posisi pengukuran yakni sebanyak 9 posisi, tapi data yang di tampilkan hanya 3 posisi di sepanjang transek pengukuran.

Tabel 2. Luaran Analisis Kuat Penerangan Untuk 3 Posisi Dalam Transek Pengukuran

\begin{tabular}{|c|c|c|c|c|c|c|}
\hline \multirow{2}{*}{ Posisi } & \multirow{2}{*}{ Jum. Data } & \multirow{2}{*}{ Rerata } & \multirow{2}{*}{ Varian } & \multicolumn{2}{|c|}{ Koefisien Fourier } & \multirow{2}{*}{$\begin{array}{c}\text { Sum. } \\
\text { Keragaman }\end{array}$} \\
\hline & & & & $A j$ & $B j$ & \\
\hline 1 & 415.50 & 31.962 & 293.627 & $\begin{array}{r}-21.318 \\
-4.664\end{array}$ & $\begin{array}{l}-9.148 \\
-3.101\end{array}$ & 96.981 \\
\hline
\end{tabular}




\begin{tabular}{|lrrrrrr|}
3 & 409.90 & 31.531 & 285.607 & -20.947 & -8.984 & 96.950 \\
& & & & -4.935 & -3.156 & \\
& 195.40 & 15.031 & 71.704 & -10.398 & -5.128 & 96.545 \\
\hline
\end{tabular}

Berdasarkan hasil penelitian yang disajikan 51armo 2, sehingga penyusunan fungsi Fourier persamaan (2) untuk 51armonic kuat penerangan yakni terdiri dari banyaknya data haromonik, rerata, koefisien Fourier $(A j$ dan $B j$ ) dimana menghasilkan data sumbangan keragaman untuk ke-3 posisi yang berbeda sepanjang transek pengukuran. Maka fungsi Fourier kuat penerangan menjadi:

Posisi 1(4 meter di luar hutan mangrove) :

$$
I(t)=31.962-21.318 \sin (2 \pi t) / 12-9.148 \cos (2 \pi t) / 12-4.664 \sin (4 \pi t) / 12-3.101 \cos (4 \pi t) / 12
$$

Posisi 3 (terpi/batas hutan mangrove) :

$$
I(t)=31.531-20.947 \sin (2 \pi t) / 12-8.984 \cos (2 \pi t) / 12-4.935 \sin (4 \pi t) / 12-3.156 \cos (4 \pi t) / 12
$$

Posisi 9 (32 meter ke dalam hutan mangrove) :

$$
I(t)=15.031-10.398 \sin (2 \pi t) / 12-5.128 \cos (2 \pi t) / 12-1.612 \sin (4 \pi t) / 12-1.196 \cos (4 \pi t) / 12
$$

Setelah ke-3 fungsi Fourier kuat penerangan diketahui, maka dapat dilukiskan untuk memperlihatkan fluktuasi kuat penerangan pada masing-masing posisi pengukuran sepanjang transek ditunjukan oleh gambar 1.

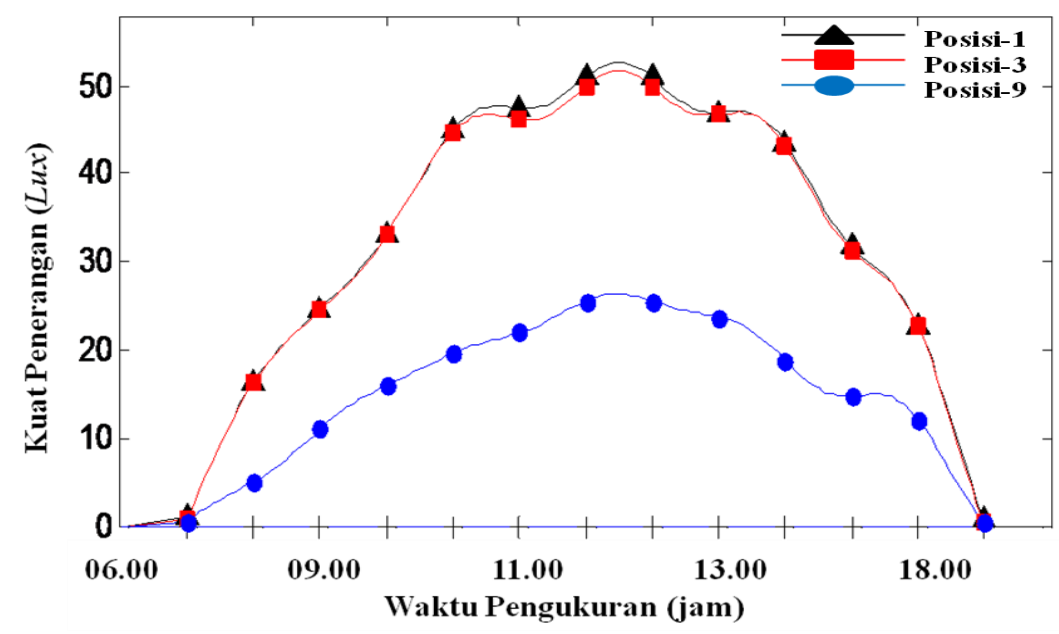

Gambar 1. Grafik Pemodelan Fungsi Fourier Kuat Penerangan Untuk 3 Posisi Yang Berbeda Di Sepanjang Transek Pengukuran. Posisi 1 (4 meter di luar hutan mangrove); Posisi 3 (tepi/batas hutan mangrove); dan Posisi 9 (32 meter ke dalam hutan mangrove).

Grafik fungsi ke-3 posisi 51 armonic kuat penerangan memperlihatkan pola sinusoidal separuh periode. Sesungguhnya skala kuat penerangan dalam penelitian ini dibagi dengan 1000 lux. Grafik kuat penerangan minimum terjadi pada pukul 18.00 yakni 0,308 lux dan kuat penerangan maksimum tercapai pada pukul 12.00 sebesar 51,210 lux. Khusus posisi 3 ke posisi 9 kuat penerangan mencapai nilai maksimum sebesar 25,400 lux pada pukul 12.00. Luaran penelitian ini sejalan dengan hasil penelitian Dalengkade [30] yang mengukur kuat penerangan pada hutan mangrove berbatasan dengan laut. Dari hasil penelitian Dalengkade tercatat bahwa kuat penerangan minimum yakni 0,310 lux pada pukul 06.00 dan kuat penerangan maksimum sebesar 59,500 lux pukul 12.00. Sedangkan dalam penelitian Dalengkade posisi 3 ke posisi 9 nilai kuat penerangan maksimum lebih tinggi yakni 34,300 lux pukul 12.00. Perbedaan yang terjadi pada posisi 3 ke posisi 9, karena dalam penelitian ini panas yang dihasilkan oleh matahari mampu direduksi oleh mangrove. Sedangkan dalam penelitian Dalengkade matahari yang memanasi permukaan laut, kemudian menggenangi mangrove dimana proses penguapan udara dari laut sangat cepat terjadi. Tapi adanya tutupan kanopi mangrove mengakibatkan perlambatan pelepasan udara panas (proses penguapan) ke area terluar. Selain itu hasil penelitian ini sejalan dengan penelitian Yi [31] yakni pemodelan distribusi transfer momentum kecepatan aliran panas yang dibawah 51 armon terhadapat indeks tutupan kanopi. 


\subsection{Pemodelan Suhu Udara $(T)$}

Luaran pemodelan menggunakan fungsi Fourier persaman (2) untuk suhu udara pada 3 posisi berbeda sepanjang transek pengukuran ditunjukkan oleh Tabel 3.

Tabel 3. Luaran Analisis Suhu Udara Untuk 3 Posisi Dalam Transek Pengukuran

\begin{tabular}{|c|c|c|c|c|c|c|}
\hline \multirow{2}{*}{ Posisi } & \multirow{2}{*}{ Jum. Data } & \multirow{2}{*}{ Rerata } & \multirow{2}{*}{ Varian } & \multicolumn{2}{|c|}{ Koefisien Fourier } & \multirow{2}{*}{$\begin{array}{c}\text { Sum. } \\
\text { Keragaman }\end{array}$} \\
\hline & & & & $A j$ & $B j$ & \\
\hline 1 & 713.30 & 28.532 & 12.177 & $\begin{array}{r}1.398 \\
-1.103\end{array}$ & $\begin{array}{r}-4.543 \\
0.568\end{array}$ & 99.080 \\
\hline 3 & 713.70 & 28.548 & 12.049 & $\begin{array}{r}1.425 \\
-1.141\end{array}$ & $\begin{array}{r}-4.498 \\
0.578\end{array}$ & 99.174 \\
\hline 9 & 706.00 & 28.240 & 8.800 & $\begin{array}{r}1.744 \\
-0.999\end{array}$ & $\begin{array}{r}-3.613 \\
0.499\end{array}$ & 98.531 \\
\hline
\end{tabular}

Berdasarkan analisis yang dipaparkan Tabel 3, maka fungsi Fourier berdasarkan persamaan (2) disusun atas data jumlah 52armonic, rerata, koefisien Fourier $(A j$ dan $B j$ ), dimana menghasilkan data sumbangan keragaman yang berbeda untuk setiap posisi pengukuran. Sehingga persamaannya menjadi :

Posisi 1 (4 meter di luar hutan mangrove) :

$T(t)=28.532+1.398 \cos (2 \pi t) / 12-4.543 \sin (2 \pi t) / 12-1.103 \cos (4 \pi t) / 12+0.568 \sin (4 \pi t) / 12$

Posisi 3 (tepi/batas hutan mangrove) :

$T(t)=28.548+1.425 \cos (2 \pi t) / 12-4.498 \sin (2 \pi t) / 12-1.141 \cos (4 \pi t) / 12+0.578 \sin (4 \pi t) / 12$

Posisi 9 (32 meter ke dalam hutan mangrove) :

$T(t)=28.240+1.744 \cos (2 \pi t) / 12-3.613 \sin (2 \pi t) / 12-0.999 \cos (4 \pi t) / 12+0.499 \sin (4 \pi t) / 12$

Diketahuinya fungsi Fourier suhu udara dari ke-3 posisi berbeda sepanjang transek pengukuran, maka dapat digambarkan grafik fungsi tersebut sebagai berikut:

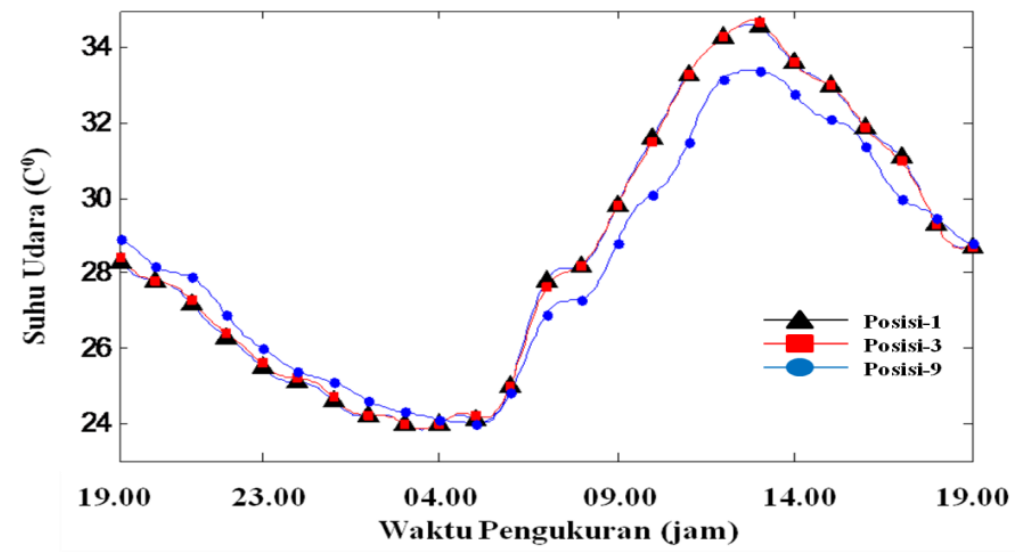

Gambar 2. Grafik Pemodelan Fungsi Fourier Suhu Udara Untuk 3 Posisi Yang Berbeda Di Sepanjang Transek Pengukuran. Posisi 1 (4 meter di luar hutan mangrove); Posisi 3 (tepi/batas hutan mangrove); dan Posisi 9 (32 meter di dalam mangrove)

Fluktuasi suhu udara yang diperlihatkan oleh Gambar 2 menunjukkan grafik sinusoidal satu periode. Dari hasil penelitian ini suhu udara minimum yakni $24,0^{\circ} \mathrm{C}$ terjadi pada pukul 03.00 dan suhu udara maksimum tepat pukul 13.00 sebesar $34,6^{\circ} \mathrm{C}$. Selain itu grafik suhu udara memperlihatkan selisih maksimum pada malam hari yakni $0,5^{\circ} \mathrm{C}$ sedangkan siang hari $1,8^{\circ} \mathrm{C}$. Hasil penelitian ini berbeda dengan peneliti sebelumnya [30] yang mengukur suhu udara hutan mangrove berbatasan dengan laut yakni $3,6^{\circ} \mathrm{C}$ pada siang hari. Penyebab perbedaan tersebut, karena dalam penelitian ini panas yang meningkatkan suhu udara hanya berasal dari cahaya matahari yang menembus celah kanopi mangrove. Sedangkan pada peneliti sebelumnya peningkatan disebabkan oleh cahaya matahari menembus celah kanopi mangrove dan proses penguapan dari 
laut. Disamping itu selisih suhu udara dalam penelitian ini, pada siang hari berbeda dengan penelitian [32] tercatat $2^{0} \mathrm{C}-4^{0} \mathrm{C}$ tapi menunjukan rentang yang sama dengan penelitian [30]. Hasil penelitian ini berbeda dengan hasil penelitian [33], [34], [35], [36], [37], [38], [39] untuk hutan di kawasan pegunungan. Mereka mencatat perbedaan maksimum suhu udara siang hari dari ketinggian $1,5 \mathrm{~m}-2 \mathrm{~m}$ di atas permukaan tanah bervariasi antara $3^{0} \mathrm{C}-6^{0} \mathrm{C}$. Sedangkan suhu udara malam hari dalam penelitian ini berbeda dengan laporan [35] yakni tercatat suhu udara malam hari $1^{0} \mathrm{C}$. Secara umum hasil penelitian ini menunjukan siklus perubahan suhu udara pada malam hari lebih rendah dibandingkan dengan siang hari.

\subsection{Pemodelan Kelembaban Udara $(H)$}

Luaran pemodelan kelembaban udara untuk 3 posisi berbeda sepanjang transek pengukuran dirangkum dalam Tabel 4.

Tabel 4. Luaran Analisis Kelembaban Udara Untuk 3 Posisi Dalam Transek Pengukuran

\begin{tabular}{|c|c|c|c|c|c|c|}
\hline \multirow{2}{*}{ Posisi } & \multirow{2}{*}{ Jum. Data } & \multirow{2}{*}{ Rerata } & \multirow{2}{*}{ Varian } & \multicolumn{2}{|c|}{ Koefisien Fourier } & \multirow{2}{*}{$\begin{array}{c}\text { Sum. } \\
\text { Keragaman }\end{array}$} \\
\hline & & & & $A j$ & $B j$ & \\
\hline 1 & 1849.80 & 73.992 & 79.283 & $\begin{array}{r}-4.038 \\
2.028\end{array}$ & $\begin{array}{l}11.502 \\
-2.083\end{array}$ & 99.047 \\
\hline 3 & 1848.30 & 73.932 & 78.073 & $\begin{array}{r}-4.117 \\
2.147\end{array}$ & $\begin{array}{r}11.354 \\
-2.114\end{array}$ & 99.236 \\
\hline 9 & 1861.80 & 74.472 & 60.473 & $\begin{array}{r}-4.949 \\
2.121\end{array}$ & $\begin{array}{r}9.325 \\
-1.903\end{array}$ & 98.858 \\
\hline
\end{tabular}

Luaran yang tertera pada Tabel 4 di atas, sehingga fungsi Fourier kelembaban udara berdasarkan persamaan (2) tersusun atas data jumlah harmonik, rerata, dan koefisien Fourier ( $A j$ dan $B j$ ) menghasilkan data sumbangan keragaman untuk 3 posisi pada transek pengukuran. Maka fungsi Fourier kelembaban udara dituliskan sebagai berikut:

Posisi 1 (4 meter di luar hutan mangrove) :

$$
H(t)=73.992-4.038 \cos (2 \pi t) / 12+11.502 \sin (2 \pi t) / 12+2.028 \cos (4 \pi t) / 12-2.083 \sin (4 \pi t) / 12
$$

Posisi 3 (tepi/batas hutan mangrove) :

$$
H(t)=73.932-4.117 \cos (2 \pi t) / 12+11.354 \sin (2 \pi t) / 12+2.147 \cos (4 \pi t) / 12-2.114 \sin (4 \pi t) / 12
$$

Posisi 9 (32 meter ke dalam hutan mangrove) :

$$
H(t)=74.472-4.949 \cos (2 \pi t) / 12+9.325 \sin (2 \pi t) / 12+2.121 \cos (4 \pi t) / 12-1.903 \sin (4 \pi t) / 12
$$

Setelah fungsi kelembaban udara untuk 3 posisi pengukuran diketahui, maka grafik kelembaban udara ditunjukkan oleh Gambar 3.

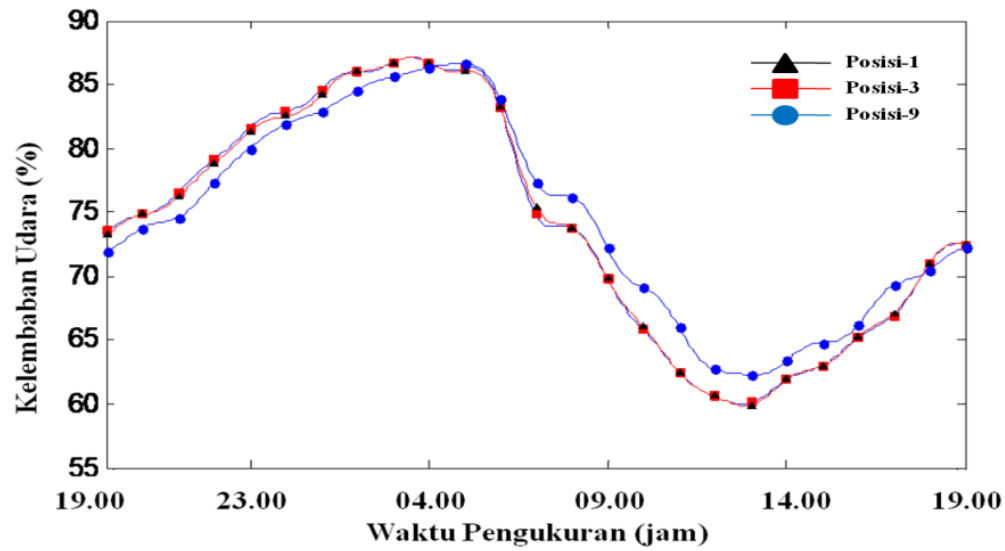

Gambar 3. Grafik Pemodelan Fungsi Fourier Kelembaban Udara Untuk 3 Posisi Yang Berbeda Di Sepanjang Transek Pengukuran. Posisi 1 (4 meter di luar hutan mangrove); Posisi 3 (tepi/batas hutan mangrove); dan Posisi 9 (32 meter di dalam hutan mangrove).

Grafik fungsi kelembaban udara di atas memperlihatkan pola sinusoidal satu periode. Pemaparan grafik kelembaban udara berbanding terbalik dengan grafik suhu udara pada Gambar 2. Perbedaan grafik tersebut 
karena terjadinya peningkatan suhu udara sehingga menurunkan kelembaban udara. Hal ini terbukti dari pengukuran pukul 19.00 nilai kelembaban udara naik sampai pukul 03.00 mencapai kelembaban udara maksimum sebesar 86,70\% dan menurun kembali mencapai batas minimum sebesar 59,9\% tepat pukul 13.00 . Sedangkan selisih maksimum kelembaban udara dari posisi 3 ke posisi 9 pada malam hari $1,4 \%$ dan siang hari sebesar $2,1 \%$.

\subsection{Respon Suhu Udara $(T)$ dan Kelembaban Udara $(H)$ Terhadap Kuat Penerangan $(I)$}

Korelasi silang suhu udara dan kelemababan udara terhadap kuat penyinaran berdasarkan besarnya nilai time-delay. Di sini perubahan kuat penerangan mendahului perubahan dua variabel yang tertera dalam Tabel 5.

Tabel 5. Luaran Analisis Korelasi Dan Time-Delay Suhu Udara dan Kelembaban Udara Terhadap Kuat Penerangan

\begin{tabular}{|ccccc|}
\hline \multirow{2}{*}{$\begin{array}{c}\text { Posisi } \\
\text { Pengukuran }\end{array}$} & \multicolumn{4}{c|}{ Time-Delay di Setiap Posisi Sepanjang Transek Pengukuran } \\
\cline { 2 - 5 } & \multicolumn{2}{c|}{ Suhu Udara $(\boldsymbol{T})$} & Kelembaban Udara $(\boldsymbol{H})$ \\
\cline { 2 - 5 } & Koef. Kor & Time-Delay & Koef. Kor & Time-Delay \\
\hline $\mathbf{1}$ & 0,967 & 1,0 & 0,973 & 1,0 \\
$\mathbf{2}$ & 0,968 & 1,0 & 0,976 & 1,0 \\
$\mathbf{3}$ & 0,966 & 1,0 & 0,974 & 1,0 \\
$\mathbf{4}$ & 0,974 & 1,1 & 0,978 & 1,1 \\
$\mathbf{5}$ & 0,981 & 1,1 & 0,982 & 1,1 \\
$\mathbf{6}$ & 0,982 & 1,1 & 0,983 & 1,2 \\
$\mathbf{7}$ & 0,981 & 1,1 & 0,985 & 1,2 \\
$\mathbf{8}$ & 0,978 & 1,1 & $0 ., 983$ & 1,2 \\
$\mathbf{9}$ & 0,978 & 1,2 & 0,984 & \\
\hline
\end{tabular}

Pemodelan dan analisis korelasi serta penentuan time-delay dilakukan per posisi sepanjang transek penelitian. Seperti yang dijelaskan dalam metode penelitian, dihasilkan koefisien korelasi silang dan timedelay pada Tabel 5. Koefisen korelasi yang terjadi, saat fungsi kuat penerangan matahari digeser mundur sejauh $t=d$ (time-delay antara perubahan suhu udara maupun kelembaban udara terhadap kuat penerangan). Dari luaran analisis yang dimuat dalam Tabel 5, maka didapatkan pola time-delay sepanjang transek pengukuran ditunjukan oleh Gambar 4.

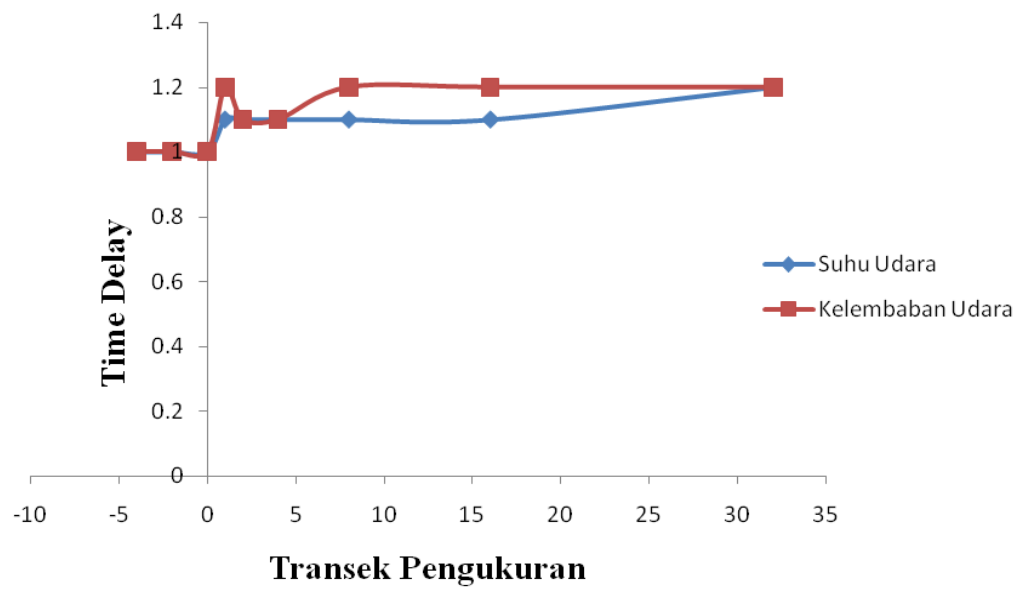

Gambar 4. Grafik Time-Delay Kuat Penerangan Terhadap Suhu Udara Dan Kelembaban Udara

Seperti yang terlihat dari Gambar 4, grafik time-delay warna biru $(T)$ dan merah $(H)$ secara konsisten dari posisi 1 ke posisi 3 yakni 1,0 jam. Sedangkan posisi 3 ke posisi 9 yakni 1,2 jam. Perbedaan tersebut, karena dari posisi 1 ke posisi 3 tidak dan kurangnya tutupan kanopi mengakibatkan terjadinya pemanasan langsung oleh cahaya matahari sehingga difusi udara sangat cepat terjadi. Berbeda dengan posisi 3 ke posisi 
9 dimana cahaya matahari mampu diredam oleh kanopi mangrove sehingga difusi udara melambat. Disamping itu time-delay suhu udara dalam penelitian ini konsisten dengan laporan penelitian [30] yakni 1,0 jam untuk posisi 1 sampai posisi 3. Tapi posisi 3 sampai posisi 9 dalam penelitian ini yakni 1,0 jam sampai 1,2 jam, sedangkan penelitian [30] untuk posisi 3 sampai posisi 9 sebesar 1,0 jam sampai 1,3 jam. Hal tersebut karena perbedaan kondisi batas ekosistem mangrove dan tutupan kanopi mangrove.

\section{KESIMPULAN}

Berdasarkan uraian hasil penelitian dan pembahasan mengenai variabel kuat penerangan, suhu udara, dan kelembaban udara pada ekosistem mangrove, maka dapat disimpulkan:

1. Menggunakan fungsi Fourier $f(t)=T_{0} \sum_{m=0}^{N / 2} a_{m} \cos \omega_{m} t+b_{m} \sin \omega_{m} t$ guna menganalisis variabel kuat penerangan, suhu udara, dan kelembaban udara menghasilkan profil perubahan variabel tersebut selama 24 jam. Maka profil tersebut dapat digunakan untuk memantau perubahan ekosistem mangrove.

2. Hasil penelitian memperlihatkan variabel suhu udara dan kelembaban udara yakni dikontrol oleh variabel kuat penerangan.

3. Posisi tepi/batas tambalan eksisitem mangrove berdasarkan hasil di atas yakni mampu mereduksi perubahan variabel kuat penerangan, suhu udara, dan kelembaban udara.

4. Walaupun hasil penelitian dari variabel kuat penerangan, suhu udara, dan kelembaban udara mampu menggambarkan karakteristik ekosistem mangrove. Tapi perlu kembali mengkaji variabel suhu lumpur/payau yang menggenangi mangrove, karena aktivitas (dekomposisi) biota dalam lapisan permukaan bumi dikontrol oleh variabel suhu dan kelembaban tanah.

5. Pemodelan di atas dapat dikembangkan guna menganalisis variasi temporal posisi tepi/batas ekosistem untuk mengetahui perbedaan organisme. Karena secara spesifik respon organisme terhadap fluks termal antara lain dapat diprediksi dari kesesuaian organisme dengan parameter cuaca seperti : intensitas matahari, suhu udara, dan kelembaban udara

6. Hasil penelitian di atas dapat dijadikan landasan oleh pemerintah terkait pemantauan wilayah pesisir, dan sebagai landasan untuk pembukaan lahan (peralihan ekosisitem pesisir menjadi daerah pemukiman maupun lahan pertanian).

\section{DAFTAR PUSTAKA}

[1] J. McHale, "Climate Change," A Threat of the Era," Sensitivity of Mangrove Ecosystem to Changing Climate. New Delhi : Springer, 2013. 1-31.

[2] D. W. Hadi , "Miliki 23\% Ekosistem Mangrove Dunia Indonesia Tuan Rumah Konferensi Internasional Mangrove 2017," 14 Maret 2017, [Online]. Tersedia: http://ppid.menlhk.go.id/siaran_pers/browse/561 [Diakses: 6 Juli 2019].

[3] D. C. Donato, J. B. Kauffman, D. Murdiyarso, S. Kurnianto, M. Stidham and M. Kanninen, "Mangroves Among the Most Carbon-Rich Forests in the Tropics," Nature Geoscience, vol. 4, pp. 293-297, April 2011.

[4] Y. R. Noor, M. Khazali dan I. N. N. Suryadiputra, "Panduan Pengenalan Mangrove Di Indonesia", Bogor: PHKA/WI-IP, 2006.

[5] J. Penman, M. Gytarsky, T. Hiraishi, T. Krug, D. Kruger, R. Pipatti, L. Buendia, K. Miwa, T. Ngara, K. Tanabe and F. Wagner, Intergovernmental Panel on Climate Change : Good Practice Guidance for Land Use Land-Use Change and Forestry. Japan: Institute for Global Environmental Strategies (IGES) for the IPCC, 2003.

[6] H. Keith, B. G. Mackey and D. B. Lindenmayer, "Re-evaluation of Forest Biomass Carbon Stocks and Lessons from the World's Most Carbon-Dense Forests," PNAS, vol. 106, pp. 11635-11640, July 2009.

[7] A. Hooijer, M. Silvius, H. Wösten and S. Page, PEAT- $\mathrm{CO}_{2}$ : Assessment of $\mathrm{CO}_{2}$ Emissions from Drained Deatlands in SE Asia., Delft Hydraulics Report Q3943, 2006.

[8] E. Mcleod, G. L. Chmura, S. Bouillon, R. Salm, M. Björk, C. M. Duarte, C. E. Lovelock, W. H. Schlesinger and B. R. Silliman, "A Blueprint for Blue Carbon: Toward an Improved Understanding of the Role of Vegetated Coastal Habitats in Sequestering $\mathrm{CO}_{2}$," Frontiers in Ecology and the Environment, vol. 9, pp. 552-560, Juny 2011.

[9] Y. Mazda and K. Kamiyami, "Tidal Deformation and Inundation Characteristics Within Mangrove Swamps," Mangrove Science, vol. 5, pp. 21-29, 2007.

[10] E. Granek and B. I. Ruttenberg, "Changes In Biotic and Abiotic Processes Following Mangrove Clearing," Estuarine Coastal and Shelf Science, vol. 80, pp. 555-562, October 2008.

[11] R. J. Davies-Colley, G. W. Payne and M. van Elswijk, "Microclimate Gradients Across a Forest Edge," New Zealand Journal of Ecology, vol. 24, pp. 111-121, 2000. 
[12] K. J. Hennenberg, D. Goetze, J. Szarzynski, B. Orthmann, B. Reineking, I. Steinke and S. Porembski, "Detection of Seasonal Variability in Microclimatic Borders and Ecotones Between Forest and Savanna," Basic and Applied Ecology, vol. 9, pp. 275-285, February 2008.

[13] J. Chen, S. C. Saunders, T. R. Crow, R. J. Naiman, K. D. Brosofske, G. D. Mroz, B. L. Brookshire and J. F. Franklin, "Microclimate in Forest Ecosystem and Landscape Ecology," BioScience, vol. 49, pp. 288-297, April 1999.

[14] M. E. Harmon, J. F. Franklin, F. J. Swanson, P. Sollins, S. V. Gregory, J. D. Lattin, N. H. Anderson, S. P. Cline, N. G. Aumen, J. R. Sedell, G. W. Lienkaemper, K. Jr. Cromack and K. W. Cummins, "Ecology of Coarse Woody Debris in Temperate Ecosystems," Advances in Ecological Research, Volume 15. Orlando: Academic Press Inc. 1986. 133-302.

[15] H. A. Fowells and J. E. Means, "The Tree and Its Environment," Silvics of North America, Volume 1 Conifers. Washington Forest Service United States Department of Agriculture. 1990. 1-11.

[16] P. V. Ridd and T. Stieglitz, "Dry Season Salinity Changes in Arid Estuaries Fringed by Mangroves and Saltflats," Estuarine Coastal and Shelf Science, vol. 54, pp. 1039-1049, July 2002.

[17] S. R. Gradstein, "Epiphytes of Tropical Montane Forests-Impact of Deforestation and Climate Change," Biodiversity and Ecology Series, vol. 2, pp. 51-65, January 2008.

[18] R. D. Moore, D. L. Spittlehouse and A. Story, "Riparian Microclimate and Stream Temperature Response to Forest Harvesting: A Review," Journal of the American Water Resources Association, vol. 41, pp. 813-834, Agustus 2005.

[19] S. Godefroid, S. Rucquoij and N. Koedam, "Spatial Variability of Summer Microclimates and Plant Species Response Along Transects Within Clearcuts in a Beech Forest," Plant Ecology, vol. 185, pp. 107-121, Desember 2006.

[20] U. Berger, V. H. Rivera-Monroy. T. W. Doyle, F. Dahdouh-Guebas, N. C. Duke, M. L. Fontalvo-Herazo, H. Hildenbrandt, N. Koedam, U. Mehlig, C. Piou and R. R. Twilley, "Advances and Limitations of Individual-Based Models to Analyzeand Predict Dynamics of Mangrove Forests: A review,” Aquatic Botany, vol. 89, pp. 260-270, December 2008.

[21] R. N. Palilingan and M. M. Pungus. “Aplikasi Analisis Fourier Dalam Fisika Lingkungan”. Kosentrasi Fisika: Lingkungan Jurusan Fisika FMIPA UNIMA, 2010.

[22] H. Dym and H. P. McKean. "Fourier Series and Integrals". New York: Academic Press Inc, 1972.

[23] M. R. Spiegel. “Fourier Analisis”. New York: McGraw-Hill Inc, 1974.

[24] P. Bloomfield. "Fourier Analysis of Time Series: An Introduction”. New York: John Wiley \& Sons Inc. 2000.

[25] G. S. Campbell.” An Introduction to Environmental Biophysics”. New York: Springer-Verlag, 1977.

[26] Q. T. Vo, C. Kuenzer, Q. M. Vo, F. Moder and N. Oppelt, "Review of Valuation Methods for Mangrove Ecosystem Services," Ecological Indicators, vol. 23, pp. 431-446, April 2012.

[27] C. S. Medellu and D. Tulandi, "Parameter: The Area of Microclimate Gradient Diurnal Dynamic for Characterization and Monitoring of Forest Ecosystem and Environment," International Journal of Environment Agriculture and Biotechnology, vol. 3, pp. 934-943, May-June 2018.

[28] C. S. Medellu, "The Area and Index of Diurnal Dynamic of Microclimate Gradient as a Mangrove-Environment Interaction Parameter," Journal of Natural Sciences Research, vol. 3, pp. 68-77, 2013.

[29] V. Bewick, L. Cheek and J. Ball, "Statistics review 7: Correlation and regression,” Critical Care, vol. 7, pp. 451459, November 2003.

[30] M. N. Dalengkade, "Pemodelan Reaksi Suhu Udara Terhadap Penyinaran Cahaya Matahari Dalam Hutan Bakau," Barekeng, vol. 13, pp. 061-068, Agustus 2019.

[31] C. Yi, "Momentum Transfer within Canopies,"Journal of Applied Meteorologi and Climatology, vol. 47, pp. 262275. January 2008.

[32] D. L. Spittlehouse, R. S. Adams and R. D. Winkler. Forest, Edge and Opening Microclimate at Sicamous Creek. Research report 24, British Columbia: Ministry of Forests Forest Science Program, 2004.

[33] G. Williams-Linera, "Vegetation Structure and Environmental Conditions of Forest Edges in Panama," Journal of Ecology, vol. 78, pp. 356-373. Juny 1990.

[34] A. Young and N. Mitchell, "Microclimate and Vegetation Edge Effects in a Fragmented Podocarp-Broadleaf Forest in New Zealand," Biological Conservation, vol. 67, pp. 63-72, February 1994.

[35] J. Chen, J. F. Franklin and T. A. Spies, "Growing-Season Microclimatic Gradients from Clearcut Edges Into OldGrowth Douglas-Fir Forests," Ecological Applications, vol. 5, pp. 74-86, January 1995.

[36] M. L. Cadenasso, M. M. Traynor and S. T. A. Pickett, "Functional Location of Forest Edges: Gradients of Multiple Physical Factors," Can J For Res, vol. 27, pp. 774-782, January 1997.

[37] K. D. Brosofske, J. Chen, R. J. Naiman and J. F. Franklin, "Harvesting Effects on Microclimatic Gradients from Small Streams to Uplands in Western Washington," Ecological Applications, vol. 7, pp. 1188-1200, November 1997.

[38] B. E. Potter, R. M. Teclaw and J. C. Zasada, "The Impact of Forest Structure on Near-Ground Temperatures During Two Years of Contrasting Temperature Extremes," Agricultural and Forest Meteorology, vol. 106, pp. 331-336, September 2001.

[39] R. J. Stathers, T. Newsome, M. J. Waterhouse and C. Sutherland. "Microclimate Studies on a Group Selection Silvicultural System in a High-Elevation ESSFwc3 Forest in the Cariboo Forest Region". Working Paper 58. British Columbia: Ministry of Forests Forest Science Program, 2001. 
[40] N. J. Georgi and K. Zafiriadis, "The Impact of Park Trees on Microclimate in Urban Areas," Urban Ecosyst, vol. 9, pp. 195-209, May 2006. 